\title{
SPIRITUALISASI KURIKULUM DI INDONESIA (Telaah Filsafat Kurikulum dalam Konteks Keindonesiaan)
}

\author{
Farikhah \\ HIPKIN (Himpunan Pengembang Kurikulum Indonesia) \\ Jawa Tengah, Indonesia. \\ farikhahrika@ymail.com
}

\begin{abstract}
Abstrak
Tulisan ini bertujuan untuk menelaah tentang perkembangan pemahaman kurikulum saat ini sesuai dengan spiritual kebangkitan di abad ke-21 dan bagaimana upaya dalam melaksanakan spiritualisasi kurikulum yang dilakukan dalam konteks KTSP, setelah penundaan kurikulum-2013. Tulisan ini menggunakan pendekatan filsafat kurikulum dalam konteks Indonesia dengan memeriksa kasus adopsi strategi rohani dengan teori kecerdasan majemuk sebagai dasar untuk pengembangan kurikulum pendidikan Islam. Hasil penelitian ini menunjukkan bahwa pembelajar yang dikembangkan melalui pendidikan dengan strategi rohani yang terintegrasi dengan dasar kecerdasan majemuk dalam banyak kasus mampu menciptakan nilai budaya produk yang bermanfaat bagi orang-orang pada umumnya. Oleh karena itu, kurikulum harus dikembangkan dengan benar-benar memperhatikan aspek kecerdasan dan potensi spiritual yang kemudian direkonstruksi ke kurikulum yang khusus dalam bentuk sehari penuh.
\end{abstract}

Kata kunci: spiritualisasi kurikulum, materialisme, kecerdasan, Pendidikan Islam

\footnotetext{
Abstract

THE SPIRITUALIZATION OF CURRICULUM IN INDONESIA (STUDY OF THE CURRICULUM PHILOSOPHY IN THE
} 
CONTEXT OF INDONESIA). This paper discusses the development of the understanding of the current curriculum in line with this spiritual awakening in the 21st century and how the efforts to spiritualize the curriculum can be done in the context of the KTSP, after a delay of Curriculum-2013. This paper uses the philosophy of curriculum approach in the context of Indonesian by examining the case of the adoption of the spiritual strategy with the theory multiple intelligences as a basis for the development of Islamic education curriculum. The result of the research show that learners that are developed through education with spiritual strategy integrated with basis of multiple intelligences in many cases able to create cultural value products that are beneficial for the people in general. Therefore curriculum must be developed by really pay attention to aspects of intelligence and spiritual potential which is then reconstructed into a specialized curriculum in the form of X-day.

Keywords: curriculum spiritualization, materialism, intelligences, Islamic education

\section{A. Pendahuluan}

Baru-baru ini dunia pendidikan terutama para guru dan praktisi pendidikan di Indonesia sedang dibingungkan dengan kebijakan Kementerian Kebudayaan, Pendidikan Dasar dan Menengah (KPDM) yang baru dengan terbitnya surat edaran Nomor: 179342/MPK/KR/2014, terkait penundaan Kurikulum 2013 (K-13). Diantara beberapa alasannya antara lain karena adanya berbagai masalah konseptual yang dihadapi antara lain mulai dari soal ketidakselarasan antara ide dengan desain kurikulum hingga soal ketidakselarasan gagasan dengan isi buku teks. Sedangkan masalah teknis penerapan terutamanya berbeda-bedanya kesiapan sekolah dan guru, belum meratanya dan tuntasnya pelatihan guru dan kepala sekolah, serta penyediaan buku pun belum tertangani dengan baik.

Dengan alasannya tersebut maka akhirnya untuk sementara K-13 sudah diterapkan di 6.221 sekolah sejak Tahun Pelajaran 2013/2014 dan rencana akan diterapkan di semua sekolah di seluruh tanah air pada Tahun Pelajaran 2014/2015 terpaksa mengalami penundaan dan kembali menggunakan kurikulum 2006 yang dikenal dengan Kurikulum Tingkat Satuan Pendidikan (KTSP). Sementara pada saat yang sama pendidikan kita juga terkesan membawa peserta didik seakan hanya dipersiapkan menjadi -meminjam istilah Mochtar 
Bukhori- sebagai "tukang-tukang” yang siap sebagai tenaga kerja yang menghasilkan keuntungan material (profit oriented). Kondisi ini klop dengan situasi bangsa yang oleh Gus Mus disebut sebut sebagai "negeri daging”. Dalam sajak Gus Mus bertajuk "Negeri Daging” dinyatakan: "di negeri daging; setiap hari banyak orang asyik memperagakan daging; setiap hari banyak orang; hilir-mudik menjajakan daging di negeri daging; setiap hari banyak orang mati; memperebutkan daging; di negeri daging jagal-jagal berkeliaran; daging-daging berserakan" (A. Mustofa Bisri, 2002).

Ketika pendidikan cenderung materialistik, segalanya diukur dari untung-rugi secara ekonomik belaka, maka hal ini sama artinya dengan mengkondisikan peserta didik menjadi hedonistikmaterialistik, terasingkan dari nilai-nilai moral-spiritual. Karena kurikulum apapun namanya baik itu KTSP atu K-13 selama dimensi spiritualitas diabaikan baik dalam desain maupun implementasinya, maka pendidikan masih akan mengalami keterseokan. Yang lebih memperihatinkan lagi, meskipun KTSP yang secara paradigmatis memberi keleluasaan kepada setiap satuan pendidikan untuk mengembangkan desain kurikulumnya secara khas dan unik bahkan juga peluang untuk memberikan muatan lokal (mulok) terobosan yang selaras dengan kondisi geografis, sosial-budayanya, seringkali masih mengalami problematik dalam mengkonstruksi kurikulum secara kontekstual dan humanis.

Padahal kurikulum digagas tak lepas dari kebutuhan peserta didik dan stake holder dimana sekolah itu berada, baik secara sosial, kultural, maupun spiritual. Konteks sosio kultural barangkalai sudah terlalu sering menjadi diskursus kajian kurikulum bahkan salah satu landasan terpenting dalam pengembangan kurikulum adalah landasan sosial budaya, disamping landasan filsafat, psikologi, dan perkembangan IPTEK. Namun landasan spiritual seringkali tidak mendapatkan ruang dalam konteks pengembangan kurikulum, pada pada hakekatnya manusia adalah makluk spiritual karena potensi fitrah yang diberikan Allah Swt sejak lahir (QS. Ar-Rum: 30).

Kajian berupaya mengkaji ulang tentang perkembangan pemahaman kurikulum terkini di tengah kebangkitan spiritual di abad ke-21 serta bagaimana upaya spiritualisasi kurikulum bisa dilakukan dalam konteks KTSP, setelah penundaan K-13. 
Farikhah

\section{B. Pembahasan}

\section{Kurikulum sebagai Teks Spiritual}

Dalam perkembangan pemikiran tentang kurikulum kontemporer sebagaimana dalam buku Understanding Curriculum (William F. Pinar, 2004: 606) salah satu kesadaran global tentang kurikulum antara lain dipahamai sebagai teks teologi (as theological text). Pemahaman kurikulum sebagai teks teologi bukan sekedar menghubungkan kurikulum dengan gereja atau kurikulum dengan materi ritual keadamaan tertentu. Lebih jauh dari itu kurikulum perlu dipahami sebagai kajian tentang moralitas, etika, sistem nilai, hermenetik, kosmologi dan keyakinan keagamaan. Hal ini berarti juga bahwa kurikulum perlu dipahami sebagai teks spiritual dalam lintas iman dan lintas budaya.

Karena itu konteks kurikulum sebagai teks teologis bukan sekedar perdebatan doa di awal belajar itu sebagai penting atau tidak, atau bagaimana rumusan doa itu harus diseragamkan sebagaimana baru-baru ini menjadi polemik akibat lontaran menteri KKPDM, Anis Baswedan. Tetapi bagaimana menjadikan dimensi spiritual dan teologi sebagai salah satu landasan dalam menformulasikan ide kurikulum, konstruksi kurikulum hingga implementasi dan evaluasinya. Dalam hal ini kurikulum perlu dari sudut pandang moral, etika dan estetika (William F. Pinar, 2004: 629).

Konsekuensinya dalam berbagai kegiatan pendidikan dan pembelajaran mulai dari penyusunan desian kurikulum, implementasi dan evaluasi juga perlu menjadikan modal spiritual sebagai landasan pijakan. Bukan sekedar berorientasi pada pemenuhan pasar kerja tetapi bagaimana membawa atau mengkondisikan peserta didik mampu hidup dan beradaptasi mengatasi berbagai persoalan kemanusiaan yang dihadapinya. Menurut Danah, dunia kepemimpinan termasuk dalam kepemimpinan pendidikan seharusnya memadukan tiga modal yang dimiliki. Pertama adalah modal material. Ia dibentuk oleh kecerdasan rasional (IQ), berfungsi menjawab pertanyaan-pertanyaan rasional seperti, “apa yang saya pikir”. Kedua, modal sosial, diukur dengan tingkat kepercayaan di masyarakat, saling merasakan, empati, serta komitmen terhadap masyarakat. Hal ini dibentuk oleh kecerdasan emosional (EQ), berfungsi menjawab pertanyaan-pertanyaan yang 
menyangkut perasaan, seperti, “apa yang saya rasakan”. Ketiga adalah modal spiritual, dalamnya termasuk modal moral yang dibentuk oleh kecerdasan spiritual (SQ). Hal ini dibangun dengan mengeksplorasi secara spiritual pertanyaan-pertanyaan seperti; "untuk apa saya ada, apa tujuan hidup saya, apa yang sebenarnya ingin saya capai” (Zohar, 2010: 1-8).

Dengan pengertian ini, maka SQ akan selalu menemukan makna dibalik segala apa yang dilakukan oleh seseornag sehingga segala tindakan dan kebijakan kepemimpinan kurikulum benar-benar bermakna dan memberi manfaat bagi orang-orang dan lingkungannya. Kalau digambarkan dalam bentuk bagan relasi ketiga kecerdasan dalam proses rekonstruksi kurikulum berbasis spiritual dapat penulis illustarasikan sebagai berikut:

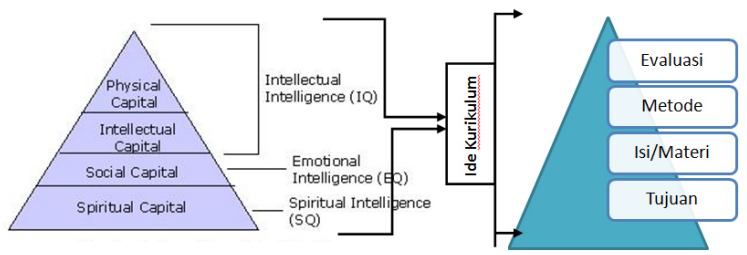

Gambar 1: Bagan relasi IQ EQ dan SQ dalam Konstruksi Kurikulum sebagai Teks Spiritual (Dikembangkan dari gagasan Zohar dan Ian Marshall)

Namun sayang seringkali terjadi kesalahpahaman dalam sebagian kalangan pendidik yang memahami kurikulum sekedar dokumen, bahkan sebagian menganggap kurikulum sekedar sebagai mata pelajaran. Hal ini berakibat pada proses pembelajaran (instructional) seakan hanya menyampaikan materi pelajaran (transfer of knowledge) saja, kering dari nilai. Maka ketika tema-tema inti bahasan sudah disampaikan, proses pembelajaran sudah dianggap selesai, lalu tinggal membuat soal-soal untuk ujian. Pembelajaran lalu sekedar menjalankan "ritual akademik" yang kering makna karena spirit meaning full learning tak ada lagi.

Padahal pemahaman kurikulum setidaknya dapat dilihat dalam tiga sisi; pertama kurikulum sebagai konstruksi gagasan/ide yang kemudian terformulasikan dalam wujud dokumentasi baik yang tertulis maupun tidak tertulis yang merencanakan kualitas 
pembelajaran atau dalam bahasa Oliva curriculum itself is a construct or concept, a verbalization of an extremely complex idea or set of ideas (Peter F. Oliva, 1997: 12). Karena itu setiap penyelenggaraan proses pembelajaran tak lepas dari adanya konsep/ide tertentu dalam menggapai tujuan pembelajaran.Dengan memahami kurikulum sebagai teks spiritual dan hal ini dijadikan sebagai ide dasar dalam merekonstruksi gagasan baru tentang kurikulum di berbagai jenjang dan jalur, maka penyusunan kurikulum dalam pengertian kedua yaitu kurikulum sebagai dokumen. Pemahaman kurikulum pada tingkat ini biasa disebut dengan kurikulum potensial, artinya ketika gagasan kurikulum dibangun dengan basis landasan spiritual, maka dokumen kurikulum yang meliputi aspek tujuan, isi, metode dan evaluasi akan turut mewarnai dalam formula komponen kurikulum sebagai dokumen tadi. (Sudjana, 1991: 7).

Ketiga, kurikulum juga dapat dilihat dalam sisi sebagai implementasi. implementasi kurikulum merupakan proses interaksi antara fasilitator sebagai penegembangan kurikulum, dan peserta didik sebagai subjek belajar. (Mulyasa, 2009: 179). Karena itu dalam sisi kurikulum sebagai implementasi proses pembelajaran dalam hal ini dapat disebut sebagai kurikulum nyata (real curriculum). Dalam konteks ini pemahaman mengenai pengertian implementasi ternyata mengalami pergeseran/perkembangan yang lebih progresif.

Kemudian implementasi kurikulum dapat juga diartikan sebagai aktualisasi kurikulum tertulis (written curriculum) kedalam bentuk pembelajaraan. Implementasi dapat juga diartika sebagai pelaksanaan dan penerapan. Ada beberapa pendapat yang dikutip dari Binti Maunah diantaranya pendapat Majone dan Wildavky (1979) yang menegemukakan bahwa implementasi adalah perluasan aktivitas yang saling menyesuaikan (dalam pressma. dan Wildavzky, 1984). Implementasi juga dapat diartikan sebagai suatu proses penerapan ide dan konsep. Adapun kurikulum dapat diartikan dokumen kurikulum (kurikulum potensial) (Hidayati, 2012: 98).

Standar nasional pendidikan berfungsi sebagai pengikat kurikulum tingakat satuan pendidikan yang dikembangkan oleh setiap sekolah dan satuan pendidikan di berbagai wilayah dan daerah. Implementasi kurikulum marupakan proses penerapan ide, konsep, kebijakan, atau inovasi dalam suatu tindakan praktis sehingga 
memberikan perunahan pengetahuan, keterampilan maupun nilai dan sikap, sedangakan implementasi kurikulum adalah suatu proses penerapan kurikulum dalam komponen satuan mata pelajaran sebagai aktualisasi kurukulum tertulis kedalam bentuk pembelajaran (Mulyasa, 2009: 2). Karena itu, beberapa hal yang harus diperhatikan dalam konteks implementasi kurikulum terkait dengan komponenkomponen pembelajaran antara lain rumusan tujuan, isi, metode, media dan evaluasi. berikut.

Implementasi Kurikulum dipengaruhi oleh tiga faktor

1. Karakteristik kurikulum; yang mencakup ruang lingkup ide baru suatu kurikulum dan kejelasaanya bagi pengguna di lapangan.

2. Strategi implementasi: yaitu strategi yang digunakan dalam implementasi, seperti diskusi profesi, seminar, penataran, loka karya, penyediaan buku kurikulum, dan kegiatan-kegiatan yang dapat mendorong penggunaan kurikulum di lapangan.

3. Karakteristik pengguna kurikulumyang meliputi pengetahuan, keterampilan, nilai, dan sikap guru terhadap kurikulum, serta kemempuanya untuk merealisasikan kurikulum dalam pembelajaran. (Mulyasa, 2009: 179-180)

\section{Dari Kurikulum 2013 kembali KTSP}

Sebagai sebuah bangsa yang hidup sebagai bagian dari dunia global yang selalu mengalami perubahan dan perkembangan ilmu pengetahuan dan teknologi harus terbuka dalam merespon perubahan itu. Demikian juga dalam dunia pendidikan. Sebagai konsekuensinya kurikulum juga harus berubah ketika kondisi sosial dan perkembangan dunia ilmu pengetahuan juga berubah. Tak perlu alergi dengan perubahan kurikulum.

Hal ini juga telah lama ditegaskan oleh pakar kurikulum Peter F. Oliva (1992: 39-41) menegaskan curriculum is a product of its time curriculum responds to and is changed by social forced, philosophical positions, psychological principles, accumulating knowledge, and educational leadership at its moment in history. Dengan kata lain suatu proses pembelajaran harus digali dari akar budaya dan latar sejarah yang melatarbelakanginya dan seimbang antara kebutuhan 
lokal, nasional dan global. Karena itu, ketika pemerintahan SBY telah mengamanatkan berlakukanya K-13 dan ternyata dalam pemerintahan Jokowi K-13 dinilai belum siap yang kemudian atas kebijakan kementerian KPDM terpaksa kembali kepada KTSP alias Kurikulum 2006, hal ini tak perlu risau. Sesungguhnya KTSP memberi peluang untuk dikembangklan menjadi sebuah kurikulum unggulan di sekolahnya masing-masing asal kepemimpinan kurikulum benarbenar dilakukan dengan kreatif, inovatif dan progresif disusun secara mandiri oleh setiap satuan pendidikan bersama stake holder terkait dan menjadikan modal spiritual sebagai salah satu landasannya.

Keberadaan KTSP yang diberlakukan sejak tahun 2006 yang kemudian sempat diganti dengan K-13 sejak tahun 2013, yang kemudian sejak 5 Desember 2014 kembali lagi pada KTSP. KTSB sebenarnya secara potensial bisa dikembangkan dengan semangat penyusunan kurikulum berbasis dari bawah, meskipun Badan Standar Nasional Pendidikan (BSNP) memberikan rambu-rambu berdasarkan Standar Kompetensi Lulusan (SKL) dan Standar Isi (SI). Maka dari ide kurikulum dan rekonstruksi kurikulum potensial menjadi kurikulum aktual setiap satuan pendidikan memiliki peluang mengembangkannya dalam proses inovasi implementasi.

Dalam proses implementasi kurikulum perlu memperhatikan filosofi pendidikan yang tak lepas dari dua proses yang saling terkait: (1) proses hominisasi, yaitu memposisikan manusia sebagai makhluk hidup di dalam dunia atau ekologinya. Karena itu pendidikan disamping harus mengkondisikan peserta didik sadar akan jati dirinya yang hidup dalam suatu bangsa dengan suatu ikatan budaya dan filsafat hidup yang menjadi ideologi bersama dan sekaligus sebagai sub-kultur dengan segala keunikan nilai dan budaya lokal yang disinggahinya. (2) proses humanisasi, yaitu memposisikan manusia sebagai makhluk yang bermoral. Sebagai makhluk bermoral manusia tak sekedar hidup, tetapi hidup untuk mewujudkan eksistensi sebagai manusia yang berbudaya berikut kesadaran religiusitas yang dimilikinya. Kesadaran kultural dan spiritual juga turut mengkonstruksi identitas sehingga membentuk habitus segala kekayaan modal sosial, budaya dan modal simbolik yang perlu dimaknai dan berdayakan sehingga menjadi tindakan bermakna (Bourdieu, 1986: 422). Karena, itu dalam pengembangan kurikulum dari ide, rekonstruksi dokumen 
hingga implementasinya perlu juga memperhatikan keunikan lokasi dan suasama sosial budaya dimana pendidikan dan pembelajaran itu diselenggarakan. Karena itu agar pendidikan tetap mempertahankan ideologi bangsa untuk mencapai tujuan nasional dan juga tidak tercerabut dari tradisi dan potensi lokal yang ada, maka perlu melandasi semangat implementasi kurikulum yang berbasis pada potensi lokal atau populer disebut place-based curriculum development (PBCD) atau dalam istilah Laurie Brady (1983) disebut sebagai School-Based Curruculum Developmen (SBCD). SBCD merupakan pengembangan kurikulum yang berbasis pada teori pendidikan berbasis lokasi (place-based education) yaitu konsep pendidikan dengan pendekatan holistik yang lebih mengedepankan pengembangan masyarakat dan konservasi lingkungan agar berkelanjutan secara progresif. Dalam prosesnya berusaha mengintegrasikan proses pembelajaran dengan konteks lingkuangan (sosial, budaya, ekonomi, geografi) peserta didik dari semua usia.

Mengingat KTSP juga mengamanatkan adanya komponen mata pelajaran muatan lokal (mulok) yang dalam panduan penyusunan KTSP diartikan sebagai kegiatan kurikuler untuk mengembangkan kompetensi yang disesuaikan dengan ciri khas dan potensi daerah, termasuk keunggulan daerah, yang materinya tidak dapat dikelompokkan ke dalam mata pelajaran yang ada, atau materinya terlalu banyak sehingga harus menjadi mata pelajaran tersendiri. Substansi mata pelajaran muatan lokal ditentukan oleh satuan pendidikan, tidak terbatas pada mata pelajaran keterampilan (Panduan KTSP, BSNP 2006).

Hal ini berarti bahwa setiap satuan pendidikan diberikan kesempatan mendesain mulok sesuai kebutuhan daerahnya. Namun karena belum siapnya SDM di daerah, kebijakan KTSP dengan muatan lokalnya ini seringkali justru menjadi persoalan tersendiri, sehingga muatan lokal yang ada, sekedar ada untuk memenuhi kewajiban UU atau Permen, tidak melalui penggalian dan penelusuran yang serius dari kekayaan khazanah budaya atau potensi lokal di daerah yang bersangkutan. Sehingga sekedar bahasa Jawa sebagai mulok hanya karena sekolahnya di Jawa, mulok Bahasa Sunda karena sekolahnya di wilayah Bandung dan sekitarnya. Memang tak ada yang salah dengan dengan mulok Bahasa Lokal tersebut, bahkan bahasa 
lokal tetap harus diajarkan sebagai sebuah kesadaran budaya untuk meningkatkan kecerdasan budaya peserta didik dimana sekolah itu berada. Namun mulok bisa juga digagas dengan sebuah terobosan dengan memadukan perkembangan ilmu pengatahuan terkini. Misalnya saja ketika muncul perkembangan teori kecerdasan majmuk (multiple intellegence) seperti dikembangkan oleh Gardner pada tahun 1983, maka hal ini bisa dijadikan sebagai inspirasi basis ilmiah dalam mengembangkan mulok terobosan.

\section{Spiritualisasi Kurikulum Mulok melalui X-day}

Kecerdasan jamak yaitu pandangan baru tentang kecerdasan yang dikemukakan Gadner (seperti yang dituliskan Thomas Amstrong "Menerapkan Multiple Intelligences di Sekolah" Kaifa 2004 hal 2), meliputi kecerdasan linguistik, kecerdasan matematislogis, kecerdasan spasial, kecerdasan kinestetis-jasmani, kecerdasan musikal, kecerdasan interpersonal, kecerdasan intrapersonal, dan kecerdasan natural.

Maka katika mulok terobosan didesain dengan melandaskan perkembangan teori MI dipadu dengan kesadaran spiritual bahwa Allah Swt menciptakan manusia itu dengan sebaik-baik bentuk (QS. At-Tin [95] : 4) dengan segala potensi fitrah yang bersifat spiritual (QS. Ar-Rum [30]: 30), KTSP bisa memberikan mulok terobosan dengan sehari penuh secara khusus (baca: X-day) untuk mengantarkan peserta didik menjadi para juara di bidangnya masing-masing.

Dengan perspektif MI, setiap peserta didik memiliki salah satu kecerdasan yang menonjol entah pada ranah Linguistik (kecerdasan bahasa), Logic Smart (kecerdasan logika matematika), Body Smart (kecerdasan fisik), Picture Smart (kecerdasan visual spasial), Self Smart (kecerdasan intrapersonal), people Smart (kecerdasan interpesonal), Music smart (kecerdasan musikal), atau Nature Smart (kecerdasan natural). Maka dalam penerimaan peserta didik tak perlu lagi dengan seleksi karena setiap anak asumsinya adalah cerdas. Tugas orang tua dan guru selanjutnya adalah memetakan potensi unggul kecerdasan peserta didik. Hal ini bisa dilakukan dengan metode Multiple Intellegences Research (MIR) atau dengan analisis sidik (finger print analysis) sebagaimana akhir-akhir ini lagi marak dikembangkan. 
MIR dilakukan dengan pengamatan dan pendampingan intensif terhadap peserta didik dengan memperhatikan gejala kegemaran sehari-hari baik dari segi perilaku gaya belajar maupun gerak-gerik baik dalam tindakan, ucapan maupun penampilan. Guru dan orang tua yang sensitif tentu akan tak terlalu sulit untuk menangkap tanda-tanda dibalik kehidupan peserta didik baik di kelas maupun di luar kelas. Sementara metode finger print analysis adalah sebuah metode untuk membantu mengenali potensi seseorang (anak, remaja, dewasa) melalui pengamatan terhadap 10 sidik jari tangan. Metode pengerjaannya mudah dan sederhana, hanya dengan scanning kesepuluh sidik jari kemudian data tersebut diolah dengan sistem komputer yang sudah dipersiapkan secara khusus. Maka kurikulum perlu didesaian dalam bentuk transaksional antara kebutuhan peserta didik dengan kurikulum itu sendiri. Bahkan dalam konteks mendesain mulok terobosan perlu merumuskan X-day sebagai hari istimeawa dalam mengembangkan potensi kecerdasan peserta didik secara lebih intensif disamping mata pelajaran pendukung pada harihari lainnya sebagai satu kesatuan dalam KTSP. X-day dalam hal ini perlu ditonjolkan karena seringkali dalam implementasi kurikulum para guru dalam banyak kasus dikejar oleh tarjet capaian materi dalam setiap semester, sehingga mengabaikan kecerdasan potensial dalam MI yang dimiliki oleh setiap peserta didik. Imlementasi kurikulum X-day ini akan menjadi hari-hari yang ditunggu-tunggu oleh peserta didik, karena X-day dipersiapkan secara khusus untuk mengembangkan potensi unggulan sesuai ranah kecerdasan yang ditonjolkan. .

Kurikulum X-day ini disusun bersama oleh peserta didik sementara guru sebagai fasilitator. Konstruksi ide kurikulum X-day ini merupakan endapan dari hasil analisis MIR dan Finger Print Analysis yang kemudian didialogkan dengan peserta didik secara transaksional dengan memperhatikan lingkungan kelas, sekolah dan juga masyarakat sekitar. Kalau digambarkan dalam bentuk bagan posisi kurikulum $\mathrm{X}$-day ini dapat penulis illustrasikan sebagai berikut:

Dengan pola pengembangan kurikulum seperti di atas, maka kurikulum peserta didik (kata lain dalam kurikulum X-day) akan mendapatkan proporsinya yang jelas, terencana dan spesial. Kendatipun demikian di tengah semaraknya tren teori MI yang telah merevolusi pembelajaran dunia pendidikan di berbagai belahan 
dunia, sejumlah sekolah Islam yaitu sekolah yang dikelola oleh yayasan yang mengembangkan dan mentransformasikan nilai-nilai Islam melalui pendidikan; telah menjadikan MI sebagai salah satu dasar inovasi dalam pengembangan kurikulumnya. Sekolah-sekolah tersebut biasanya lebih menjadikan dirinya sebagai agen transformasi sosial dalam turut membangun karakter dan prestasi peserta didik.

Sekolah Islam pertama di Indonesia yang secara sistemik mengembangkan kurikulum pendidikan karakter berbasis MI adalah SMA Plus Muthahhari Bandung (SMATH) yang dipeloporo oleh Jalaluddin Rahmad (Kang Jalal) sejak tahun 1992. SMATH merupakan lembaga pendidikan yang dibentuk dari perubahan pesantren mahasiswa. Sebagaimana sistem pesantren di Indonesia yang kedudukannya khas, karena disamping menjadi alternatif pembangunan yang berpusat pada masyarakat itu sendiri (peopleentered development) juga sekaligus sebagai pusat pengembangan pembangunan yang berorientasi pada nilai (value-oriented development (Azra, 1997: xx1), maka SMATH juga dikembangkan dengan didasarkan pada ilmu-ilmu modern namun bersamanya dikenalkan ilmu-ilmu Islam tradisional.

Dengan prinsip seperti itulah maka SMATH mencoba mengembangkan kurikulumnya dengan berbasis MI. Yang menarik, meskipun dalam usianya yang relatif muda pada tahun 2002, SMATH mendapat penghargaan Kementrian Pendidikan Republik Indoensia dijadikan salah satu sekolah uji coba pelaksanaan KBK (Kurikulum Berbasis Kompetensi) dari 40 SMA se-Indonesia dan salah satu sekolah uji coba pelaksanaan PBK (pendidikan Berwawasan Khusus: Kepribadian dan Budi Pekerti) dari delapan sekolah yang ditunjuk Depdiknas Pusat. Tahun 2005 ditunjuk sebagai Sekolah berbasis TIK (Teknologi Informasi dan Komunikasi) dan tahun ini dijadikan sebagai salah satu model (best practice) pendidikan karakter Indonesia sejak tahun 2010.

Pengembangan kurikulum Sekolah Islam berbasis MI semakin inovatif dan semarak setelah terbitnya buku terjemahan Thomas Armstrong dengan judul yang cukup provokatif Sekolah Para Juara (Multiple Intellegences in the Classroom) tahun 2002, yang disusul dengan terjemahan buku karya Thomas R. Hoer Buku Kerja Multiple 
Intellegences, Pengalaman New City School, tahun 2007. Semarak MI semakin menggema dalam dunia pendidikan di Indonesia setelah seorang pakar MI Indonesia, lulusan pertama studi Distance Learning di Supercamp Oceanside California, USA pimpinan Bobbi DePorter, Munif Chatib menelorkan sebuah buku dengan judul yang bombastis; Sekolahnya Manusia; Sekolah Berbasis MI di Indonesia.

Buku tersebut tersebut merupakan rekaman pengalamannya yang dalam mentransformasi sebuah sekolah di Gresik, Jawa Timur, yang semula sudah hampir bobrok, karena image negarif sekolah tersebut lantaran tak bermutu. namun dengan sentuhan Chatib melalui basis teori MI akhirnya sekolah tersebut dalam kurun waktu kurang dari 5 tahun, menjadi sekolah favorit dengan segudang prestasi di berbagai bidang dengan bangunan karakter peserta didik yang bisa diandalkan (Chatib, 2009: 4). Chatib dalam hal ini telah berhasil melakukan terobosan inovasi kurikulum berbasis MI yang sesuai dengan prinsip inovasi Rogers seperti kompatibel, kemudahan, triabilitas, dan observabilitas sehingga dengan mudah bisa diaplikasikan dan ada dampak positif yang cukup revolusioner.

Yang menarik setelah terbitnya buku tersebut Chatib hampir setiap minggu diundang diberbagai forum guru yang berminat mengadopsi pengalamannya melalui forum bedah buku, seminar dan pelatihan di berbagai penjuru nusantara hingga sekarang. Dari beberapa pengalaman pengembangan kurikulum berbasis MI tersebut memiliki beberapa indikator sebagai berikut (Chatib, 2009: 19):

\section{a. Character Building}

Prinsip ini berangkat dari kesadaran ontologis bahwa manusia hakikatnya terdiri atas dua dimensi. Dimensi jasmani dan rohani. Dua dimensi itu selayaknya harus tersentuh proses pembelajaran dalam hidup manusia. Apabila porsi pendidikan terhadap dua dimensi tersebut tidak seimbang, terutama minim pada dimensi rohani, akan terjadi "bencana akhlak" (krisis karakter bangsa). Maka dampaknya tidak ada lagi kejujuran, kepedulian, tanggung jawab, saling menghargai, dan lain-lain.

\section{b. Agent of Change}

Memposisikan sekolah sebagai agen perubahan. Sebagai konsekwensinya tidak perlu lagi ada lagi sekolah unggul dan sekolah 
“jeblok". Sekolah tidak boleh diskriminasi hanya menerima anak-anak yang pintar dalam pengertian diukur dari nilai Ujian Nasional (UN) atau ujian masuk. Dalam perspektif tidak penting mengedepankan the best input. Karena itu sistem penerimaan peserta didik baru di sekolah tidak didasarkan pada tes masuk, namun tergantung pada jumlah kursi yang tersedia. Karena itu setiap anak dianggap pintar (juara) di bidangnya masing-masing yang diidentifikasi melalui Multiple Intellegences Reseach (MIR).

\section{c. The Best Process}

Konsekuensi agent of change adalah proses pembelajaran yang terjadi di sekolah itu harus terbaik. Pembelajaran yang masuk memori jangka panjang peserta didiknya dan tidak akan lupa seumur hidup melalui pembelajaran yang bermakna (meaningfull learning). Proses pembelajaran harus mengandung kekuatan emosi positif. Mulai proses awal pembelajaran sampai akhir benar-benar menyentuh perasaan peserta didik.

\section{d. The Best Teacher}

Konsekuensi the best process menunutut the best teacher, yakni guru yang benar-benar guru yang memiliki kompetensi pedagogis, profesional, individual dan sosial. Posisi guru juga tidak lagi sebagai satu-satunya sumber belajar, karena guru yang baik berperan sebagai fasilitator. Dengan posisi ini persentase proses peserta didik belajar harus lebih besar daripada persentase proses guru mengajar. Guru yang baik juga berperan sebagai katalisator, yaitu terus berusaha memantik kemampuan peserta didik, termasuk bakatnya. Terutama kepada para peserta didik yang "lamban" dalam menerima dan memahami informasi. Bukan malah memihak kepada peserta didik yang "pandai" saja. Guru yang baik selalu berusaha menyesuaikan gaya mengajarnya dengan gaya belajar peserta didiknya. Apabila proses teaching sytle dan learning style sesuai, akan muncul kondisi sebenarnya tidak ada pelajaran yang sulit dan semua peserta didik mampu menerima informasi dari guru dengan menyenangkan.

\section{e. Applied Learning}

Konten pembelajaran di berbagai jenjang sekolah harus dapat diaplikasikan dalam kehidupan sehari-hari. Materi pembelajaran jangan sampai dijadikan "terpisah", tidak berhubungan dengan 
kehidupan sehari-hari. Minimal, peserta didik memahami manfaat materi pembelajaran, sehingga apa yang mereka pelajari merasa dibutuhkan selanjutnya memunculkan rasa cinta dan gairah sehingga menjadi habitus kehidupan budayanya.

\section{f. Manajemen Sekolah}

Dalam manajemen sekolah berbasis MI ini setidaknya membutuhkan dua perangkat; (1) context system, yaitu penyelenggara pendidikan, dan sayap kedua adalah content system, yaitu kepala sekolah dan guru. Dalam hal ini tenaga pendidik dan kependidikan di Satuan Sekolah yang mengembangkan kurikulum berbasis MI harus berjalan secara senergis menuju satu visi yang sama. Demikian juga hubungan antara mapel satu dengan yang lainnya juga harus dibangun dalam hubungan yang dialogis sehingga nilai-nilai moral yang ingin ditonjolkan bisa menjadi karakter dalam diri peserta didik.

\section{Simpulan}

Secara ontologis manusia adalah makhluk spiritual. Islam juga memandang manusia hakekatnya adalah sarat dengan potensi-potensi spiritual dalam Islam disebut sebagai potensi fitrah (QS. Ar-Rum [30]: 30). Maka pendidikan Islam diselenggarakan tak boleh terlepas dari akar spiritual yang dimiliki oleh setiap manusia sejak lahir.

Dimensi fisik adalah wadah dari spiritualitas manusia agar hidup di dunia dalam ruang dan waktu yang terbatas. Namun ketika manusia telah meninggal, dimensi fisik boleh saja hancur lebur, namun dimensi spiritualitas dari manusia akan lebih langgeng (perennis). Karena itu dimensi jiwa dan raga perlu lebih diperhatikan secara seimbang dalam pengembangan pendidikan di kini dan masa yang akan datang.

Kesadaran ontologis manusia dalam dimensi jiwa dan raga menjadi endapan pemikiran sebagai ide kurikulum, untuk direkonstruksi menjadi dokumen kurikulum. Implementasi dan evaluasi kurikulum juga tetap menggunakan landasan pacu modal spiritual sebagai basis utama kurikulum potensial maupun aktual. Maka, peserta didik dikembangkan melalui pendidikan dengan basis spiritualitas sehingga dengan kapasitasnya, mereka mampu menciptakan produk dan menawarkan layanan yang efektif dan 
Farikhah

bernilai budaya yang tentu memberi manfaat luas bagi kemaslahatan umat. Pendidikan seperti inilah yang yang disebut sebagai pendidikan bermakna pada sekolah-sekolah yang diharapkan mampu melahirkan para juara di bidangnya masing-masing. 


\section{DAFTAR PUSTAKA}

Armstrong, T. 2002. Sekolah Para Juara, Menerapkan Multipel Intellegences dalam Pendidikan. Bandung: Kaifa.

Bardy, Laurie. 1983. Curriculum Development in Australia. PrenticeHall of Australia PTY LTD.

Bisri, A.Mustofa. 2002. Negeri Daging. Yogyakarta: Bentang

Bourdieu, Pierre. 1984. Distintion: A Social Critique of the Judgement of Taste, Cambridge-MA: Harvard University Press.

. 1986. "The Forms of Capital", terj. dari Bahasa Perancis oleh Richard Nice, dalam Richardson, J.E. (ed.), Handbook of Theory of Research for the Sociology of Education, New York: Greenword Press, hlm. 46-58 1990. The Logic of Practice, California: Sanford University.

Chatib, M. 2009. Sekolahnya Manusia, Sekolah Berbasis Multiple Intellegences di Indonesia. Bandung: Kaifa.

Danah Zohar, Ian Marshal. 2005. Spiritual Capital: Memberdayakan SQ di Dunia Bisnis, Bandung: Mizan Pusataka.

Gardner, H. 1999. Intelligence Reframed: Multiple Intelligences for the 21st Century. Basic Books.

Gardner, H. 1983. Frames of Mind: The theory of multiple intelligences, New York: Basic Books.

Gardner, Howard. 2004. Kecerdasan Majemuk, Teori dalam Praktek, alih bahasa Alexander Sindoro. Batam: Interaksara.

Hasan, Said Hamid, MA. Kurikulum dan Tujuan Pendidikan. dalam http://pk.sps.upi.edu/artikel_hamid.html (on-line 22 Pebruari 2014)

Hidayati, Wiji. 2012. Pengembangan Kurikulum. Yogyakarta: Pedagogia.

Hoer, T.R. 2007. Buku Kerja Multiple Intellegences. Pengalaman New City. Bandung: Kaifa.

Koesoema A, D. 2007. Pendidikan Karakter, Strategi Mendidikan Anak di Zaman Global. Jakarta: Grasiondo. 
Farikhah

Miller, John P and Wayne Seller. 1985. Curriculum Perspectives and Practice. New York \& London: Longman.

Mulyasa, 2009. Implementasi Kurikulum Tingkat Satuan Pendidikan, Jakarta: PT Bumi Aksara,

Mulyasa. 2009. Menjadi Guru Professional. Bandung: Remaja Rosda.

Oliva, P.F. 1992. Developing the Curriculum. 4th edition. New York: Longman

Pinar, William F. 2004. Understanding Curriculum, An Introduction to Study of Historical and Contemporary Curriculum Development, New York: Peter Lang.

Sanjaya, Wina, Dr. 2008. Kurikulum dan Pembelajaran; Teori dan Praktek Pengembangan KTSP. Bandung. Kencana.

Smith, Gregory A., Place-Based Education: Learning to Be Where We Are, http://www.clearingmagazine.org/Smith.html (diakses 2 Februari 2014)

Sudjana, Nana. 1991. Pembinaan dan Pengembangan Kurikulum. Bandung: sinar baru.

Tilaar, H.A.R.,Prof. Dr., M.Sc., Ed. 1985. Paradigma Baru Pendidikan Nasional, Jakarta: Rineka Cipta.

Zohar, D. 2010. 'Exploring spiritual capital: An interview with Danah Zohar', Spirituality in Higher Education, Newsletter, vol. 5 (5) 